\title{
Massive hospital-wide bacillus outbreak related to hospital linen and construction
}

\author{
M Balm*, C Teo, R Jureen, R Lin, D Fisher \\ From International Conference on Prevention \& Infection Control (ICPIC 2011) \\ Geneva, Switzerland. 29 June - 2 July 2011
}

\section{Introduction / objectives}

At the National University Hospital in Singapore, the baseline average number of bacillus cultures/month is eight. An outbreak became evident when 274 clinical isolates of Bacillus were recovered from 230 inpatient episodes between April and August 2010. An investigation was undertaken.

\section{Methods}

Chart reviews of affected patients and extensive environmental sampling was followed by a review of hospital ventilation systems, cleaning protocols and laundry processes. Response to interventions was monitored via clinical case numbers and environmental sampling over a six month period.

\section{Results}

B. cereus complex constituted 164 cases $(71.3 \%)$. Bacteraemia comprised 207 patient episodes $(90.0 \%)$, of which 124 occurred in immunocompromised patients or those with intravascular devices. Physicians treated the organism in 68 episodes (29.5\%). Environmental investigations confirmed heavy air contamination particularly within patient rooms and air conditioned wards. Dense airborne contamination outside the hospital adjacent to large earthworks on a construction site was demonstrated $\left(\sim 600 \mathrm{CFU} / \mathrm{m}^{3}\right)$. Towels were heavily contaminated even after laundering $\left(7403 \pm 1054\right.$ spores $\left./ \mathrm{cm}^{2}\right)$. Amplification of spores occurred in clean linen due to storage conditions $\left(165 \pm 84\right.$ spores $/ \mathrm{cm}^{2}$ pre-storage vs $4437 \pm 1228 \mathrm{spores} / \mathrm{cm}^{2}$ post-storage). Interventions focusing on laundry protocols, environmental cleaning and air filtration saw clinical case numbers return to baseline levels within three months.

National University Hospital, Singapore, Singapore

\section{Conclusion}

Environmental contamination with Bacillus may be an under-recognised infection risk in hospitals exposed to construction work. Laundering and environmental cleaning processes that are not sporicidal carry a greater risk. Storage conditions of cleaned linen can amplify Bacillus contamination.

\section{Disclosure of interest}

None declared.

Published: 29 June 2011

doi:10.1186/1753-6561-5-S6-077

Cite this article as: Balm et al:: Massive hospital-wide bacillus outbreak related to hospital linen and construction. BMC Proceedings 2011 5(Suppl 6):077.
Submit your next manuscript to BioMed Central and take full advantage of:

- Convenient online submission

- Thorough peer review

- No space constraints or color figure charges

- Immediate publication on acceptance

- Inclusion in PubMed, CAS, Scopus and Google Scholar

- Research which is freely available for redistribution
C 2011 Balm et al; licensee BioMed Central Ltd. This is an open access article distributed under the terms of the Creative Commons Attribution License (http://creativecommons.org/licenses/by/2.0), which permits unrestricted use, distribution, and reproduction in any medium, provided the original work is properly cited. 